\title{
Monitoring and predicting land use change in Beijing using remote sensing and GIS
}

\author{
Qiong $\mathrm{Wu}^{\mathrm{a}, \mathrm{b}}$, Hong-qing $\mathrm{Li}^{\mathrm{b}}$, Ru-song Wang ${ }^{\mathrm{a}, *}$, Juergen Paulussen ${ }^{\mathrm{a}}$, \\ Yong $\mathrm{He}^{\mathrm{c}}$, Min Wang ${ }^{\mathrm{a}}$, Bi-hui Wang ${ }^{\mathrm{c}}$, Zhen Wang ${ }^{\mathrm{a}}$ \\ ${ }^{a}$ Key Laboratory of Systems Ecology, Research Center for Eco-Environmental Sciences, \\ Chinese Academy of Sciences, P.O. Box 2871, Beijing 100085, PR China \\ ${ }^{\mathrm{b}}$ College of Geo-Exploring, Jilin University, 6 West Minzhu Street, Changchun 100045, PR China \\ ${ }^{\mathrm{c}}$ Beijing Municipal Institute of City Planning \& Design Planning Research Department, 60 South Lishi Road, Beijing 100045, PR China
}

Received 4 March 2005; received in revised form 28 October 2005; accepted 28 October 2005

Available online 20 January 2006

\begin{abstract}
Rapid land use change has taken place in many mega cities of China such as Beijing over the past two decades. In this paper, land use change dynamics were investigated by the combined use of satellite remote sensing, geographic information systems (GIS). The results indicated that there had been a notable and uneven urban growth and a major loss of cropland loss between 1986 and 2001. Most of the urban growth and loss of agriculture land occurred in inner and outer suburbs. Land use change was projected for the next 20 years using Markov chains and regression analyses. The further integration of remote sensing and GIS technologies with Markov model and regression model was found to be useful for describing, analyzing and predicting the process of land use change.
\end{abstract}

(c) 2005 Elsevier B.V. All rights reserved.

Keywords: Land use change; Satellite remote sensing; GIS; Markov model; Urban growth; Beijing

\section{Introduction}

The intensity of land use change in response to world population growth and its consequences for the environment warrant in-depth studies of these transformations. Several international interdisciplinary research projects have been initiated during the past two decades for this purpose. These include the International Geosphere-Biosphere Project (1988) and the Land Use and Cover Change program (Messerli, 1997). Both of these projects indicated the need to construct an updated and accurate database concerning these changes, their meaning, their pace and the explanatory factors prompting their appearance (Mather, 1999). The phenomenon of urban development is one of the major forces driving land use change. In the United States, urban and built-up areas increased by $34 \%$ between 1982 and

\footnotetext{
* Corresponding author. Tel.: +86 10629 43807; fax: +86 1062943807 .

E-mail addresses: wuqiong@jlu.edu.cn(Q.Wu), lihq@jlu.edu.cn(H.-q.Li), wuqiong@jlu.edu.cn (R.-s. Wang), paulussen@mail.rcees.ac.cn (J. Paulussen), masterplan_eco@bmicpd.com.cn (Y. He),wangmrd@263.net (M. Wang), masterplan_eco@bmicpd.com.cn (B.-h. Wang),wwwzhappy@sina.com (Z. Wang).
}

1997, and this increase mainly came from the conversion of croplands and forestland (Alig et al., 2004). In China, the rapid urbanization process caused an unprecedented scale and rate of urban expansion over the last two decades (Seto and Kaufmann, 2003). Urban land will continue to expand at a rapid rate in China because more than half of its population will be urban by 2030 according to a United Nation projection (United Nations, 2001).

The issue of land use change in China is of great significance because China's per-capita land resource is far below the world's average. Prior to 1978, the government had strict control on land use planning. Growing grains was especially important because of China's large population. Since 1978, when China initiated its economic reform, rapid urbanization and economic expansion has brought about massive land developments all over the country leading to the loss of a significant amount of agriculture land (The Ministry of Land and Resources P.R.C., 2002). This is especially true in many mega cities, such as Beijing. Traditionally managed agricultural landscapes play a vital role in sustaining local biodiversity and ecosystems (Turner, 1990). Local land-use and land-cover change can influence environmental and ecological changes and furthermore contribute to global changes (Meyer 
and Turner, 1991). Fragmentation of farms in the urban fringe caused by urban sprawl has come with a loss of the traditional farming economic base and a change in the character and visual quality of rural communities (Brabec and Smith, 2002). All of these changes, especially the loss of agricultural land, have the potential to undermine the long-term harmony of humans and their environment and threaten the food security of China. There is a pressing need for knowledge about the magnitude, pattern and type of land use and land cover changes and for projecting future land development.

Beijing, the capital of China, has undergone rapid urbanization and economic growth since the economic reform in 1978. Unprecedented land use changes were witnessed in the last two decades. These land use changes have brought about many land related problems, such as water pollution, soil contamination and air pollution (Beijing Municipal Bureau of Environmental Protection, in litt.). In particular, the rapid urban expansion has resulted in the loss of large amount of agriculture land in the alluvial plain area of Beijing (Beijing Municipal Bureau of Land Resources and Housing Administration, in litt.). It is estimated that other rapid developing cities (e.g. Shanghai, Shenyang, Guangzhou) have undergone the same agriculture land loss process in China (The Ministry of Land and Resources P.R.C., 2002).

Satellite remote sensing and geographic information systems (GIS) have been widely applied in identifying and analyzing land use and land cover change (Ehlers et al., 1990; Eastman and Fulk, 1993; Harris and Ventura, 1995; Jensen and Cowen, 1999; Hathout, 2002). Satellite remote sensing provides multi-spectral and multi-temporal data that can be used to quantify the type, amount and location of land use change. GIS provides a flexible environment for displaying, storing and analyzing digital data necessary for change detection. The most widely used change detection methods are post-classification comparison and multidate composite image change detection (Jensen, 1996). Satellite remote sensing and GIS technology have been increasingly used in the examination of land use and land cover change in China, especially change related urban growth (Li and Yeh, 1998; Yeh and Li, 1999; Chen et al., 2000).

The study reported here investigated land use changes over three time periods, 1986-1991, 1991-1996 and 1996-2001, in the Beijing Municipality area, using multi-temporal remote sensing data and GIS. The impact of urban growth on the agricultural land in the urban-rural fringe was described. Regression analysis was applied to identify the spatial dependency of urban land increase and the relation between urban area change and the increase in non-agriculture population and economic factors. The Markov model was used to analyze the stochastic nature of the land use data. In addition, land use change was projected for the next twenty years using Markov matrices and regression analysis. These methods should be applicable to other regions with rapid urban urbanization.

\section{Study area}

Beijing is located between latitudes $39^{\circ} 26^{\prime} \mathrm{N}$ and $41^{\circ} 03^{\prime} \mathrm{N}$, and longitudes $115^{\circ} 25^{\prime} \mathrm{E}$ and $117^{\circ} 30^{\prime} \mathrm{E}$ and has an area of about
$16,800 \mathrm{~km}^{2}$ (Fig. 1). The geography of Beijing Municipality is characterized by alluvial plains in the south and east, except for hills and mountains that dominate in the north, northwest and west, and the total plain area is about $6300 \mathrm{~km}^{2}$. Beijing has a climate with four distinct seasons characterized by hot, humid summers (due to the East Asian monsoon) and cold, windy, dry winters (reflecting the influence of the vast Siberian anticyclone). The average annual temperature was $12.5^{\circ} \mathrm{C}$, and the average precipitation was $566.1 \mathrm{~mm}$, as recorded from 1978 to 2001 (Beijing Municipal Statistical Bureau, 2002).

Beijing is situated in the north of Northern China plain, which is a major agriculture production base of China. As the Political, Cultural and International Communication Center of China, Beijing has been expanding relatively modestly since 1949 . This expansion speeded up after the economic reform in 1978. It has experienced rapid population growth, economic increase and landscape alteration in the last two decades (Fig. 2). The urban area has increased rapidly and this increase of urban land has come predominantly from the conversion of croplands located in the plain area of Beijing (Beijing Municipal Bureau of Land Resources and Housing Administration, in litt.). The non-agriculture population increased from 4.79 million in 1978 to 9.61 million in 2001, which is a $100.6 \%$ increase (Beijing Municipal Statistical Bureau, 2002). This population increase was mainly caused by immigration. Beijing has already been confronted with increasingly overcrowded transportation systems, insufficient water supply and environmental pollution (Beijing Municipal Bureau of Environmental Protection, in litt.).

\section{Methods}

\subsection{Change detection}

Land use patterns for 1986, 1991, 1996 and 2001 were mapped by the use of Landsat TM images (October 25, 1986; May 16, 1991; May 29, 1996; May 19, 2001). It may be better to use the images of the same season for comparison. However, the autumn image in 1986 was unavailable. A modified version of the Anderson scheme of land use classification was adopted (Anderson et al., 1976). The classification schemes include: (1) urban land (the largely continuous area covered by urban constructions and urban facilities, comprising districts/counties and towns), (2) rural residential (rural villages), (3) barren land, (4) crop land, (5) forest, shrubs and horticulture and (6) water (rivers, lakes, ponds and reservoirs).

Each Landsat image was enhanced and georeferenced to the Beijing local coordinate system based on 1:50,000 scale topographic maps. All these data were resampled using the nearest neighbor algorithm to keep the original brightness values of pixels unchanged. The resultant root mean squared error of each image was less than 0.66 pixel $(19.8 \mathrm{~m})$.

Radiometric correction is necessary for detecting changes of surface reflectances. A relative radiometric correction method using image regression (Jensen, 1996) was employed, by which the brightness value of each pixel of the subject scenes were 


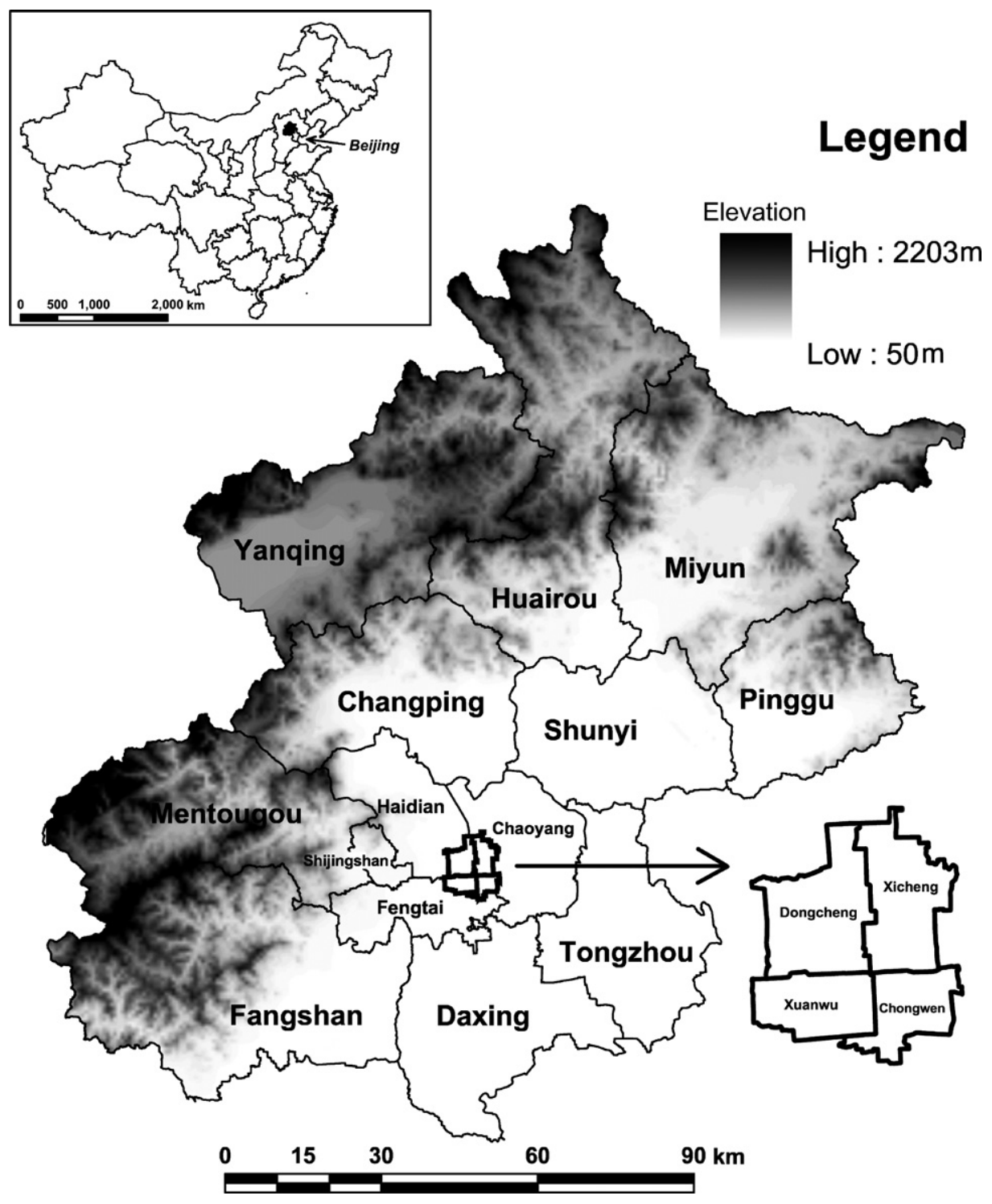

Fig. 1. A map of the study area.

related to that of the reference image (the 2001 scene) band by band to produce a linear regression equation. This image normalization method does not need any ancillary data on the atmospheric conditions during the satellite overpasses and can minimize differences in sun angle, earth-sun distance, atmospheric effects, detector calibration differences, sun-targetsensor (phase angle) geometry and soil moisture conditions between dates (Jensen, 1996).

The maximum likelihood method was used for the land use classification. Both statistical and graphical analyses of feature
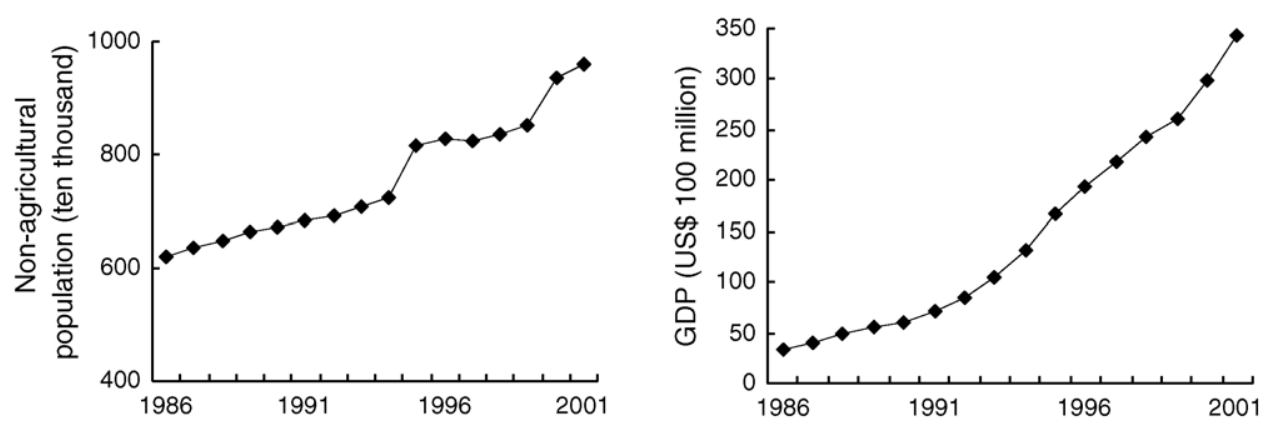

Fig. 2. Beijing non-agricultural population and GDP 1986-2001. 
selection were conducted, and bands 1-4 were found to be most effective in discriminating each class and thus used for classification. The feature selection process reduced the number of bands to be processed in the database, but should not affect the classification accuracy (Jensen, 1996). Four bands of TM 1-4 (visible and near infrared ranges) were used for the processing. Training site data were collected by means of on-screen selection of the polygon training data method. A total of 170 training sites were chosen for each image to ensure that all spectral classes constituting each land use category were adequately represented in the training statistics. The accuracy of the four classified maps was checked with a stratified random sampling method, by which 70 samples were selected for each land use category. The reference data were collected from field surveys and existing land use maps that have been field-checked. Global positioning systems were used to assist in the identification of field data on images. Large-scale aerial photos and QUICKBIRD images were also employed as reference data for the assessment of classification and accuracy. The overall accuracy of the land use maps for 1986, 1991, 1996 and 2001 was determined to be $89.32 \%, 87.66 \%$, $87.17 \%$ and $88.29 \%$, respectively. The KAPPA indices for the 1986, 1991, 1996 and 2001 maps were $0.87,0.85,0.85$ and 0.86 respectively.

In order to estimate nature, location and rate of land use change, the land use maps were overlaid with district/county boundary images, which were constructed in a vector GIS environment within the Beijing local coordinate system and converted into a raster format with the resolution of $30 \mathrm{~m}$. This GIS overlay helped to investigate land use change information within each district or county.

\subsection{Regression analysis of the land use change process}

\subsubsection{Regression analysis of the spatial dependency of land use changes}

In order to examine the driving forces that are responsible for land use change, regression analysis was applied to examine the relationships between land use changes and spatial variables. Land use changes reflect location behaviors and preferences. The spatial dependency of land use changes can be analyzed by the integration of remote sensing and GIS. In this study, urban expansion is hypothesized as a function of distance to the center of the city; that is, the increased urban land may be in a distance decay function. Regression analysis can be undertaken to verify this hypothesis. A series of $0.25 \mathrm{~km}$ wide circular buffer zones centered at the polygon center of the city are created to calculate the area of increased urban land around the city center. The relationship between the increased urban land and the distance to urban center is expressed by the following equation:

$$
\mathrm{UBN}_{\text {increased }}=a_{0}+a_{1} x
$$

where $\mathrm{UBN}_{\text {increased }}$ is the increased urban land (in ha) in the buffer zone, $a_{0}$ and $a_{1}$ are the coefficients and $x$ (in $\mathrm{km}$ ) is the distance to the urban center (polygon center of the city).

\subsubsection{Regression analysis based on the land rent maximization theory}

Land rent maximization is the theoretical basis for several decades of econometric modeling to support development of projection models of land use changes. Alig et al. (2004) tested this theory using regression analysis in the case of urban land on US landscape. In this study, we tested this theory in the case of urban land in Beijing using regression models, and the economic and demographic variables are used as proxies for rents from urban land. The 1994 cropland protection ordinance was also included in the regression model as a dummy variable. Given projections of the land use determinants, the fitted models were used to generate projections of urban land to 2006, 2011, 2016 and 2021. The regression equation estimated was

$$
\begin{aligned}
\text { URBAN }_{\text {area }}= & \beta_{0}+\beta_{1}(\text { NONAGRICULTURE POPULATION }) \\
& +\beta_{2}(\text { URBAN PER CAPITA INCOME }) \\
& +\beta_{3}(\text { RURAL PER CAPITA INCOME }) \\
& +\beta_{4}(\text { ORDINANCE })
\end{aligned}
$$

The dependent variable in the regression model was urban land area (ha). The independent variables in the regression model included non-agricultural population $(10,000)$ to account for the impact that population growth has on the expansion of urban land, per capita incomes (US\$ 1) of urban population to account for the per capita land consumption rises with real personal income, per capita incomes (US\$ 1) of rural population to account for urban land consumption is inversely related to opportunity costs of foregone agricultural production, and ORDINANCE as a dummy variable to account for the 1994 agricultural land protection ordinance.

Area data of urban land for analysis came from the four classified images, and the urban land area of each year in 1987-1990, 1992-1995 and 1997-2000 is linearly interpolated using the classified data of 1986 and 1991, 1991 and 1996, 1996 and 2001, respectively. Data of population and per capita income were from the Beijing's Statistical Yearbook 2002 (Beijing Municipal Statistical Bureau, 2002).

\subsection{Markov analysis of the land use change process}

Markov chains have been widely used to model land use changes including both urban and nonurban areas at large spatial scales (Drewett, 1969; Bourne, 1971; Bell, 1974; Robinson, 1978; Jahan, 1986; Muller and Middleton, 1994). Stationary and first-order have usually been assumed except in a few studies where the stationary or the order of Markov chains was tested (Bell, 1974; Robinson, 1978). This paper assumed land use change as a finite first-order Markov chain with stationary transition probabilities, and different categories were the states of a chain, and both time homogeneity (time stationary) and Markov property (time independence) were tested using Pearson $\chi^{2}$ goodness-of-fit tests.

A finite first-order Markov process is a stochastic process $\left\{X_{t}\right.$, $t \in T\}$ with index set $T=\{0,1,2, \ldots\}$ and a finite state space 
$N=\{1,2, \ldots, N\}$, which has the following Markov property:

$P\left\{X_{t}=j \mid X_{t-1}=i, \quad X_{t-2}=i_{t-2}, \ldots\right.$,

$\left.X_{0}=i_{0}\right\}=P\left\{X_{t}=j \mid X_{t-1}=i\right\}$

for all $t$ and all possible states $j, i, i_{k}(k=0,1, \ldots, t-2)$. This means that the probability of the random variable $X$ being in state $j$ at time $t$ depends only on the variable's state $i$ at time $t-1$, and not on states at previous points in time.

If the transition probabilities $p_{i j}(t)=P\left\{X_{t}=j \mid X_{t-1}=i\right\}$ are independent of time $t$, then the Markov chain is said to be time stationary (time homogeneous). In this event:

$p_{i j}(t)=p_{i j}, \quad t \in T$

A time-stationary Markov chain is completely determined by the Markov transition matrix $P$ :

$P=\left[\begin{array}{cccc}p_{11} & p_{12} & \ldots & p_{1 N} \\ p_{21} & p_{22} & \ldots & p_{2 N} \\ \vdots & \vdots & \ddots & \vdots \\ p_{N 1} & p_{N 2} & \ldots & p_{N N}\end{array}\right], \quad \sum_{j=1}^{N} p_{i j}=1$

and the initial distribution $s(0)=\left(s_{1}(0), s_{2}(0), \ldots, s_{N}(0)\right)$, $\sum_{i} s_{i}(0)=1$. As the time-stationary Markov chain advances in time, the distribution after the $m$ th transition period is

$s(m+1)=s(m) P$,

When a sufficiently large number steps of transition occurred, $s(t)$ reaches the limiting distribution $s^{*}=\lim _{m \rightarrow \infty} s(0) P^{m}$, which is independent of the initial distribution.

If a Markov train is time stationary and the order is set, the transitional probabilities can be estimated through the maximum likelihood estimation. This estimation is obtained by maximizing the maximum likelihood function subject to the constraint that $\sum_{j} p_{i j}=1$, and this yields

$\hat{p}_{i j}=\frac{n_{i j}}{n_{i}}=\frac{n_{i j}}{\sum_{t=1}^{T} n_{i}(t-1)}=\frac{\sum_{t=1}^{T} n_{i j}(t)}{\sum_{t=1}^{T} \sum_{j} n_{i j}(t)}$

where $n_{i j}$ is the total number of observed cells from category $i$ to $j$ over all transition periods, $n_{i}$ is the total number of cells transiting from category $i$ over the all transition periods, $n_{i}(t-1)$ is the total number of cells transiting from category $i$ during the $t$ th transition period, $n_{i j}(t)$ is the number of cells transiting from category $i$ to $j$ in the $t$ th transition period (Anderson and Goodman, 1957). This estimate is just the relative frequency of transitions observed over the entire time period.

\subsubsection{Test of time homogeneity (time stationary)}

A test of time homogeneity (time stationary) is appropriate for deciding whether the transition probabilities of a first-order Markov chain can be assumed constant over time. If so, the transition matrix will be suitable to predict land use categories in future according to Eq. (6). This test can be performed by dividing the full sample period comprising $T$ transitions into $M$ mutually exclusive and exhaustive subperiods $(m=1, \ldots, M$;
$M \leq T$ ) with equal time intervals and test whether the transition probabilities estimated for each of the $M$ subsamples are statistically different from the transition probabilities estimated for the full sample. Hypothesis tests are:

$\mathbf{H}_{\mathbf{0}}$. for each subperiod $m, p_{i j \mid m}=p_{i j}(m=1, \ldots, M), p_{i j}$ are estimated according to Eq. (7).

$\mathbf{H}_{\mathbf{a}}$. for at least one subperiod $k, p_{i j \mid k} \neq p_{i j}, p_{i j \mid m}$ are obtained by maximizing the maximum likelihood function subject to the constraint that $\sum_{j} p_{i j \mid m}=1$.

The estimator of $p_{i j \mid m}$ are $\hat{p}_{i j \mid m}=\frac{n_{i j \mid m}}{n_{i \mid m}}$, where $n_{i j \mid m}=$ $\sum_{t \in m} n_{i j \mid m}(t)$ and $n_{i \mid m}=\sum_{t \in m} n_{i \mid m}(t-1)$. This estimate is merely the relative frequency of transitions from $i$ to $j$ in the $m$ th subperiod. The test can be implemented using Pearson $\chi^{2}$ goodness-of-fit test statistics:

$K^{(M)}=\sum_{m=1}^{M} \sum_{i=1}^{N} \sum_{j \in A_{i}} n_{i \mid m} \frac{\left(\hat{p}_{i j \mid m}-\hat{p}_{i j}\right)^{2}}{\hat{p}_{i j}}$,

where $A_{i}=\left\{j: \hat{p}_{i j}>0\right\}$. Let $a_{i}$ denotes the total number of elements in $A_{i}$, this test statistics have an asymptotic $\chi^{2}$ distribution with $(M-1) \sum_{i=1}^{i=n}\left(a_{i}-1\right)$ degrees of freedom.

\subsubsection{Test of Markov property (time independence)}

If the land use change sequence is a Markov process of order 0 , the probability of the random variable $X$ being in state $j$ at time $t$ is given by

$P\left\{X_{t}=j \mid X_{t-1}=i, \quad X_{t-2}=i_{t-2}, \ldots\right.$,

$\left.X_{0}=i_{0}\right\}=P\left\{X_{t}=j\right\}$,

If the above condition does not hold, then the process is of higher degree. If the Markov chain is of order 1, the probability of the random variable $X$ being in state $j$ at time $t$ depends only on the last movement, this is the Markov property given by Eq. (3). If the chain is of order $u$, the probability of the random variable $X$ being in state $j$ at time $t$ depends on the last $u$ movements, then

$$
\begin{aligned}
& P\left\{X_{t}=j \mid X_{t-1}=i, \quad X_{t-2}=i_{t-2}, \ldots,\right. \\
& \left.X_{0}=i_{0}\right\}=P\left\{X_{t}=j \mid X_{t-1}=i,\right. \\
& \left.X_{t-2}=i_{t-2}, \ldots, \quad X_{t-u}=i_{t-u}\right\},
\end{aligned}
$$

Thus, testing Markov property is equivalent to testing that the Markov process is of order 1. There are two steps in the testing procedure. First the null hypothesis that the Markov chain is of order 0 versus order 1 is tested; then the order 1 versus order 2 is tested. If the test of order 0 against order 1 is rejected, and the test of order 1 against order 2 is accepted, the process may be assumed to be of order 1 .

To test for order 0 , the null hypothesis $\mathrm{H}_{0}$ : for each $i$, $p_{i j}=p_{j}(i=1, \ldots, N), \mathrm{H}_{\mathrm{a}}$ : for at least one $i, p_{i j} \neq p_{j}$. The maximum likelihood estimator of $p_{i j}$ under $\mathrm{H}_{0}$ is $\hat{p}_{j}=n_{j} / n$, where $n_{j}=\sum_{t} n_{j}(t)$. The Pearson $\chi^{2}$ goodness-of-fit test statistics is 
given as follows:

$K^{\left(O_{0}\right)}=\sum_{i=1}^{N} \sum_{j=1}^{N} n_{i} \frac{\left(\hat{p}_{i j}-\hat{p}_{j}\right)^{2}}{\hat{p}_{j}}$,

This test statistics has an asymptotic $\chi^{2}$ distribution with $(N-1)^{2}$ degrees of freedom.

To test for order 1 versus order 2, a second-order Markov chain is defined by considering the land categories $h(h \in N)$ at time $t-2$ and assuming that the pair of successive states $h$ and $i$ forms a composite state (Anderson and Goodman, 1957). That is, if the state space is defined as $N=\{Q, R\}$, the pair of successive states $h$ and $i$ forms a composite state $\{\mathrm{QQ}, \mathrm{QR}, \mathrm{RR}$, $\mathrm{RQ}\}$, given the transition probabilities of the time homogeneous Markov chain of order 2 is $P_{h i j}=P\left\{X_{t}=j \mid X_{t-1}=i, X_{t-2}=h\right\}$. Then, the probability of a region moving to state $j$ at time $t$, given it was in $i$ at $t-1$ and in $h$ at $t-2$, is $p_{h i j}$. The corresponding number of transition cells is $n_{h i j}(t)$, which has the marginal frequency $n_{h i}(t-1)=\sum_{j} n_{h i j}(t-1)$. To test for order 1 , the null hypothesis $\mathrm{H}_{0}$ : for each $h, p_{h j i} \neq p_{i j}(h=1, \ldots, N), \mathrm{H}_{\mathrm{a}}$ : for at least one $h, p_{h j i} \neq p_{i j}$. The $p_{h i j}$ are estimated as $\hat{p}_{h i j}=\frac{n_{h i j}}{n_{h i}}$, where $n_{h i j}=\sum_{t=2}^{T} n_{h i j}(t)$ and $n_{h i}=\sum_{t=2}^{T} n_{h i}(t-1)$ (Anderson and Goodman, 1957). The $p_{i j}$ are estimated from the full data according to (7). The Pearson $\chi^{2}$ goodness-of-fit test statistics is given as follows:

$K^{\left(O_{1}\right)}=\sum_{h=1}^{N} \sum_{i=1}^{N} \sum_{j \in B_{i}} n_{h i} \frac{\left(\hat{p}_{h i j}-\hat{p}_{i j}\right)^{2}}{\hat{p}_{i j}}$,

where $B_{i}=\left\{j: \hat{p}_{i j}>0\right\}$. The Pearson statistic $K^{\left(O_{1}\right)}$ is not defined if $n_{h i}=0$. Let $b_{i}$ denotes number of elements in $B_{i}$ and $c_{i}$ denotes number of elements in $C_{i}=\left\{h: n_{h i}>0\right\}$, this test statistics have an asymptotic $\chi^{2}$ distribution with $\sum_{i=1}^{i=n}\left(b_{i}-\right.$ 1) $\left(c_{i}-1\right)$ degrees of freedom.

\section{Results}

\subsection{Land use change in Beijing}

The quantification of land use change for the analyzed categories is given in Table 1. Forest, shrubs and horticulture was the largest class throughout the study period, which were mainly distributed in the hills and mountains where are mostly nat- ural preservation areas or state parks and changed little due to the strict control of land use change by the government. Croplands and urban lands were mainly located in the alluvial plain in the south and in the Yanqing basin in the northwest. Urban land underwent the greatest growth (from 77999.7 ha in 1986 to 116441.6 ha in 2001) during the entire study period and this urban expansion reached its zenith in the 1990s. The maximum urban land increase occurred in the second period 1991-1996 (from 80589.8 to 101709.9 ha). In 1994, the nation implemented the 'Ordinance for the Protection of Primary Agricultural Land' (State Council, 1994) to control the extremely rapid land development, and urban expansion slowed down in the third period 1996-2001 (from 101709.9 to 116441.6 ha) because of the implementation of the ordinance. The major reason of this urban expansion was immigration from other areas of China. Water increased from 65009.2 to 67660.7 ha in 1986-1996 because of the increase of fishponds in suburban areas, and decreased in 1996-2001 due to the urban expansion in the suburban areas that engrossed these fishponds. The land use transitional probabilities of subperiods 1986-1991, 1991-1996 and 1996-2001 are shown in Table 2, as are the transitional probabilities of full periods 1986-2001 which were calculated using the land use change data of three periods according to (7). Of the 49.28\% (38 442 ha) increase in urban land from 1986 to 2001, $96.99 \%$ resulted from croplands with transitional probabilities 0.00458 from 1986 to $1991,0.03851$ from 1991 to 1996 and 0.02653 from 1996 to 2001 .

The overlay of the urban expansion map with a district/county mask revealed the spatial occurrence of urban expansion within administrative regions. In absolute terms, the greatest urban expansion from 1986 to 2001 occurred in Chaoyang (8493.7 ha), followed by Fengtai (5929.2 ha), Daxing (4250.4 ha), Haidian (4074.9 ha) and Changping (3900.2 ha) (Table 3). However, in percentage term, the largest increase in urban land during the full study period occurred in Daxing (94.06\%), followed by Changping (81.11\%), Huairou (73.15\%), Fengtai (65.88\%) and Chaoyang (62.64\%) (Table 3). Massive urban sprawl in these areas could be ascribed to urban housing development and industrial development, which is a common phenomenon in mega cities after the reform of China. In the full study period of 1986-2001, urban increase occurred mainly in the inner suburbs (19913.5 ha) and outer suburbs (17344.5 ha), which indicated the 'distance decay function' of the factors influencing land development probabilities (Bruijn, 1994). More details are

Table 1

Area measurements of land use within Beijing for 1986, 1991, 1996 and 2001

\begin{tabular}{|c|c|c|c|c|c|c|c|c|c|c|}
\hline \multirow[t]{2}{*}{ Categories } & \multicolumn{2}{|l|}{1986} & \multicolumn{2}{|l|}{1991} & \multicolumn{2}{|l|}{1996} & \multicolumn{2}{|l|}{2001} & \multicolumn{2}{|c|}{ Change in 1986-2001 } \\
\hline & Area (ha) & Area $(\%)$ & Area (ha) & Area $(\%)$ & Area (ha) & Area $(\%)$ & Area (ha) & Area $(\%)$ & Area (ha) & Area $(\%)$ \\
\hline Urban land & 77999.7 & 4.76 & 80589.8 & 4.92 & 101709.9 & 6.21 & 116441.6 & 7.11 & 38441.9 & 49.28 \\
\hline Rural residential & 44303.2 & 2.70 & 44603.2 & 2.72 & 47880.1 & 2.92 & 49362.1 & 3.01 & 5058.9 & 11.42 \\
\hline Barren land & 5593.3 & 0.34 & 5445.3 & 0.33 & 5463.3 & 0.33 & 5478.3 & 0.33 & -115.0 & -2.06 \\
\hline Cropland & 549437.1 & 33.53 & 544678.8 & 33.23 & 519749.92 & 31.71 & 504485.8 & 30.78 & -44951.3 & -8.18 \\
\hline $\begin{array}{l}\text { Forest, shrubs and } \\
\text { horticulture }\end{array}$ & 896547.3 & 54.71 & 896523.9 & 54.70 & 896426.4 & 54.70 & 896329.4 & 54.69 & -217.9 & -0.02 \\
\hline Water & 65009.2 & 3.97 & 67049.3 & 4.09 & 67660.7 & 4.13 & 66792.68 & 4.08 & 1783.5 & 2.74 \\
\hline
\end{tabular}


Table 2

Land use transitional probabilities of each subperiod and the full period 1986-2001

\begin{tabular}{|c|c|c|c|c|c|c|}
\hline Categories & Urban land & Rural residential & Barren land & Cropland & $\begin{array}{l}\text { Forest, shrubs } \\
\text { and horticulture }\end{array}$ & Water \\
\hline \multicolumn{7}{|l|}{ 1986-1991 } \\
\hline Urban land & 1.00000 & 0.00000 & 0.00000 & 0.00000 & 0.00000 & 0.00000 \\
\hline Rural residential & 0.00000 & 1.00000 & 0.00000 & 0.00000 & 0.00000 & 0.00000 \\
\hline Barren land & 0.00000 & 0.00000 & 0.97354 & 0.00000 & 0.00000 & 0.02646 \\
\hline Cropland & 0.00458 & 0.00054 & 0.00000 & 0.99116 & 0.00000 & 0.00372 \\
\hline Forest, shrubs and horticulture & 0.00000 & 0.00000 & 0.00000 & 0.00000 & 1.00000 & 0.00000 \\
\hline Water & 0.00111 & 0.00000 & 0.00000 & 0.00122 & 0.00000 & 0.99768 \\
\hline \multicolumn{7}{|l|}{ 1991-1996 } \\
\hline Urban land & 1.00000 & 0.00000 & 0.00000 & 0.00000 & 0.00000 & 0.00000 \\
\hline Rural residential & 0.00000 & 1.00000 & 0.00000 & 0.00000 & 0.00000 & 0.00000 \\
\hline Barren land & 0.00000 & 0.00000 & 1.00000 & 0.00000 & 0.00000 & 0.00000 \\
\hline Cropland & 0.03851 & 0.00593 & 0.00003 & 0.95405 & 0.00000 & 0.00147 \\
\hline Forest, shrubs and horticulture & 0.00000 & 0.00004 & 0.00000 & 0.00000 & 0.99989 & 0.00007 \\
\hline Water & 0.00214 & 0.00016 & 0.00000 & 0.00145 & 0.00000 & 0.99626 \\
\hline \multicolumn{7}{|l|}{ 1996-2001 } \\
\hline Urban land & 1.00000 & 0.00000 & 0.00000 & 0.00000 & 0.00000 & 0.00000 \\
\hline Rural residential & 0.00000 & 1.00000 & 0.00000 & 0.00000 & 0.00000 & 0.00000 \\
\hline Barren land & 0.00494 & 0.00000 & 0.99506 & 0.00000 & 0.00000 & 0.00000 \\
\hline Cropland & 0.02653 & 0.00283 & 0.00008 & 0.96997 & 0.00000 & 0.00059 \\
\hline Forest, shrubs and horticulture & 0.00011 & 0.00000 & 0.00000 & 0.00000 & 0.99989 & 0.00000 \\
\hline Water & 0.01210 & 0.00016 & 0.00000 & 0.00506 & 0.00000 & 0.98268 \\
\hline \multicolumn{7}{|l|}{ 1986-2001 } \\
\hline Urban land & 1.00000 & 0.00000 & 0.00000 & 0.00000 & 0.00000 & 0.00000 \\
\hline Rural residential & 0.00000 & 1.00000 & 0.00000 & 0.00000 & 0.00000 & 0.00000 \\
\hline Barren land & 0.00164 & 0.00000 & 0.98940 & 0.00000 & 0.00000 & 0.00897 \\
\hline Cropland & 0.02310 & 0.00310 & 0.00004 & 0.97182 & 0.00000 & 0.00195 \\
\hline Forest, shrubs and horticulture & 0.00004 & 0.00001 & 0.00000 & 0.00000 & 0.99993 & 0.00002 \\
\hline Water & 0.00518 & 0.00011 & 0.00000 & 0.00259 & 0.00000 & 0.99212 \\
\hline
\end{tabular}

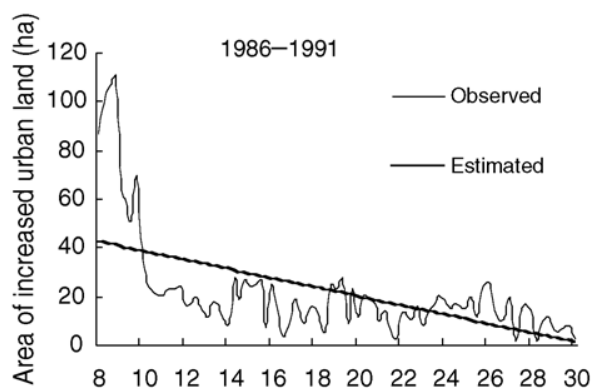

(A) Distance from the urban center $(\mathrm{km})$

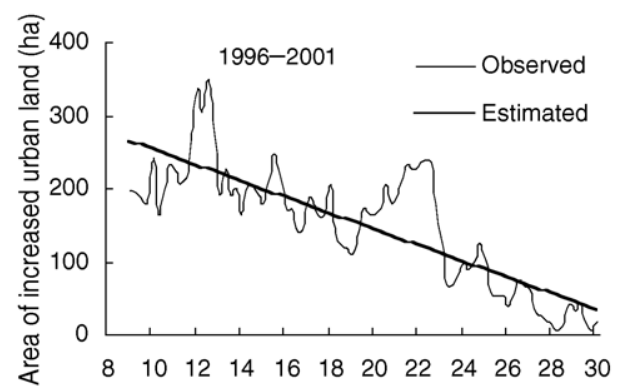

(C) Distance from the urban center (km)

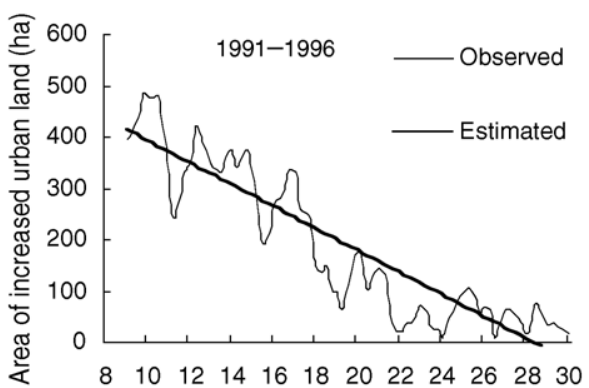

(B) Distance from the urban center $(\mathrm{km})$

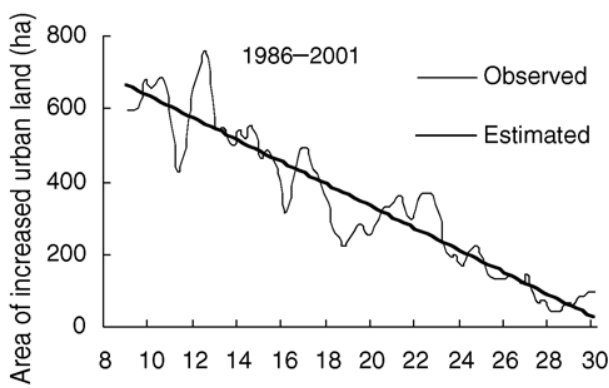

(D) Distance from the urban center $(\mathrm{km})$

Fig. 3. Spatial dependency of land use change from urban center over time periods. 


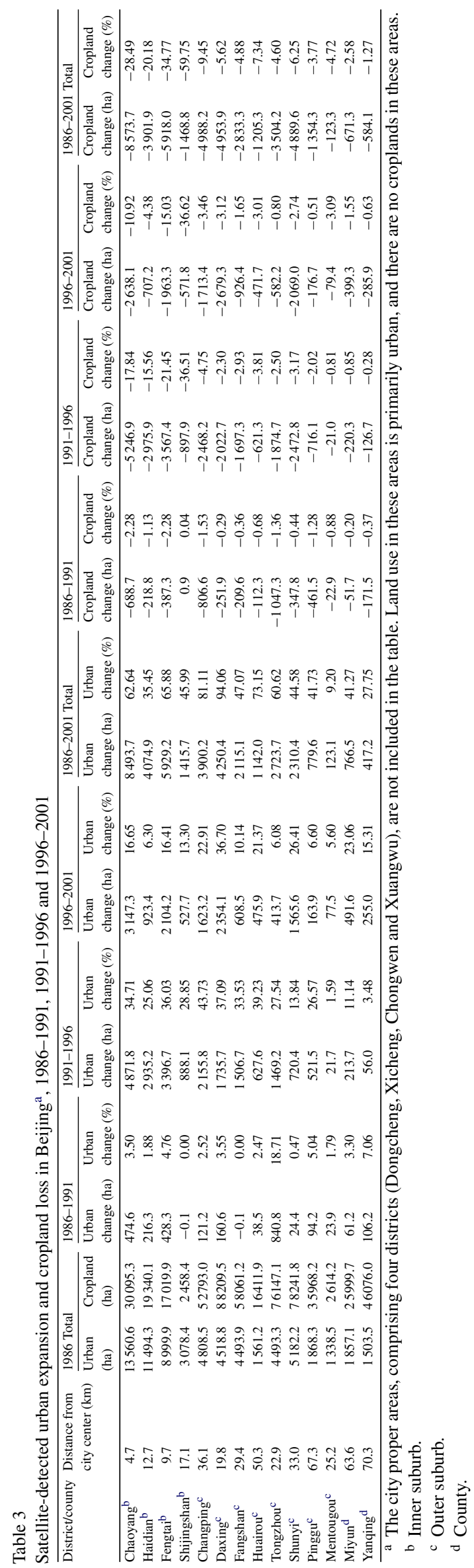

discussed in the results of regression analysis of spatial dependency. In the period of 1986-1991, urban increased little in both inner suburbs and outer suburbs. From 1991 to 1996, more land changed into urban land in the inner suburbs (12 091.8 ha) than in the outer suburbs (8758.6 ha). During the period of 1996-2001, urban land increase in outer suburbs $(7282.4 \mathrm{ha})$ is more than the increase in inner suburbs (6702.6 ha) because inner suburban areas did not have enough land on which to expand.

During the full study period, cropland decreased by 44970.2 ha in Beijing Municipality area. The transition probabilities of 1986-1991, 1991-1996 and 1996-2001 revealed that most of the cropland losses were converted to urban land or rural residential land. The overlay of cropland loss map with a district/county boundary image made it possible to generate the statistics of cropland loss found in each district/county (Table 3). Most of the cropland loss occurred in the urban fringe regions (inner and outer suburbs) located on the alluvial plain areas with good quality agricultural land. Therefore, the sustainability of agriculture is questionable given that this trend of land use change will continue.

\subsection{Regression analysis of the land use change process}

\subsubsection{Spatial dependency of land use changes}

The analysis indicates a strong spatial dependency of land use changes. Fig. 3 shows the relationships between the urban land increase and the distance to urban center. There is a strong distance decay function affecting the urban land increase. It is obvious that most of urban land increase occurred near the city center. The relationship is stronger for the period of 1991-1996 and 1996-2001 than for the period of 1986-1991. Table 4 and Fig. 3 show the regression results for the spatial dependency of increased urban land according to Eq. (1). The increased urban land declines rapidly in a linear decay function from 9 to $30 \mathrm{~km}$. The parameter $a_{0}$ is the intercept, and it only has virtual meaning since the urban center has not had an increase in urban land. However, the higher value of $a_{0}$ means that the increase in urban land near the city center for the period of 1991-1996 was higher than for the period of 1996-2001. The parameter of $a_{1}$ indicates how rapidly the urban land increases out from the center. The value of $a_{1}$ for the period of 1991-1996 is higher than the period of 1996-2001, which means the urban land increase decayed faster for the period of 1991-1996 than for the period of 1996-2001, and this decay speed change between the two periods was partly attributed to the absence of space for urban expansion near the city center since 1996. For the period of 1986-1991, though the value of $r^{2}$ is small, it is still

Table 4

The relationships between the urban land increase and the distance to urban center

\begin{tabular}{lrrrlll}
\hline Period & \multicolumn{1}{l}{$a_{0}$} & \multicolumn{1}{l}{$a_{1}$} & \multicolumn{1}{l}{$F$} & \multicolumn{1}{l}{$r^{2}$} & \multicolumn{1}{l}{$P$} & $\alpha$ \\
\hline $1986-1991$ & 57.123 & -1.872 & 43.23 & 0.34 & $<0.001$ & 0.05 \\
$1991-1996$ & 605.680 & -21.421 & 449.42 & 0.84 & $<0.001$ & 0.05 \\
$1996-2001$ & 362.337 & -10.955 & 189.37 & 0.69 & $<0.001$ & 0.05 \\
$1986-2001$ & 934.095 & -30.312 & 783.91 & 0.90 & $<0.001$ & 0.05 \\
\hline
\end{tabular}


clear from Fig. 3 that most of the urban land increased in the $8-10 \mathrm{~km}$ distance zone. The value of $r^{2}(0.90)$ for the total period of 1986-2001 indicated a strong linear correlation between the increased urban land and the distance from the center of the city. This urban land increase in a distance decay function indicates that agricultural land near the city center is more likely to be converted into urban land uses.

\subsubsection{Regression analysis based on the land rent maximization theory}

Results of the regression models are presented in Eq. (13).

$$
\begin{aligned}
& \text { URBAN }_{\text {area }} \\
& \begin{aligned}
= & 53863.51 \\
& +31.745(\text { NONAGRICULTURE POPULATION) } \\
& +28.373 \text { (URBAN PER CAPITA INCOME) } \\
& -8.970(\text { RURAL PER CAPITA INCOME) } \\
& -1945.203(\text { ORDINANCE) }
\end{aligned}
\end{aligned}
$$

The parameters obtained were: $r^{2}=0.995, F=713, P=0.000$, $\alpha=0.05$, which meant that the regression model was highly significant. The estimated coefficient for the NONAGRICULTURE POPULATION variable suggests that population amount had a positive impact on the urban land use. The variable URBAN PER CAPITA INCOME was also positive and consistent with increased consumption of land for urban uses as personal incomes of urban areas rise. The variable RURAL PER CAPITA INCOME was negative and suggests that higher personal income of rural areas would tend to reduce the consumption of land for urban uses. The variable ORDINANCE was negative, which means that the 1994 primary land protection ordinance reduced the urban land use.

Sensitivity analyses were performed by altering projected trends in non-agriculture population and personal income growth. Assumptions about the future are a major influence on projections and some insights on the relative importance of different assumptions or study limitations can be gained by altering key assumptions and assessing the effect on projections. To help guide the sensitivity analyses, the relative influence of explanatory variables in the model was assessed. Elasticities that represented the estimated change in the proportion of urban land given a $10 \%$ change in each explanatory variable were computed. Three elasticities for nondummy variables computed are: non-agriculture population, $2.47 \%$; per capita income of urban areas, $3.79 \%$; and per capita income of rural areas, $-0.46 \%$. For example, a $10 \%$ increase in personal income of urban population in the model would lead to a $3.79 \%$ increase of the urban land. The elasticities suggest that population and per capita income of urban population have the larger relative influences, although note that a single point estimate should be viewed cautiously because of the nonlinear nature of the logistic function.

\subsubsection{Predicting land use change based on the regression model}

The estimated regression model coefficients were used to project urban land area to 2021 for Beijing. Projections of urban land area involved computing projected future proportions of urban land within districts counties, based on projected values of non-agriculture population amount and other explanatory variables. The non-agriculture population, per capita income of urban areas and per capita income of rural areas in each year were all correlated to time from 1986 to 2001 by means of linear regression. The predictive model of non-agriculture population $(10,000)$, per capita income of urban area (US\$ 1) and per capita income (US\$ 1) of rural were

\section{NONAGRICULTURE POPULATION}

$$
=-43211.4+22.06 \text { YEAR }
$$

\section{URBAN PER CAPITA INCOME}

$$
=-208003.7+104.695 \text { YEAR }
$$

\section{RURAL PER CAPITA INCOME}

$$
=-73879.5+37.217 \text { YEAR }
$$

The parameters obtained for Eqs. (14)-(16) were: $r^{2}=0.937$, $F=207, P=0.000, \alpha=0.05 ; r^{2}=0.937, \quad F=208, P=0.000$, $\alpha=0.05 ; r^{2}=0.953, F=281, P=0.000, \alpha=0.05$, respectively. A closer analysis of the data (Table 5) revealed that the population density in Beijing was nearly constant during the full study period. From these three models, the non-agriculture population, per capita income of urban area and per capita income of rural

\begin{tabular}{|c|c|c|c|c|c|}
\hline Year & $\begin{array}{l}\text { Non-agriculture } \\
\text { population }(10,000)\end{array}$ & $\begin{array}{l}\text { Per capita income of urban } \\
\text { population (US\$ 1) }\end{array}$ & $\begin{array}{l}\text { Per capita income of rural } \\
\text { population (US\$1) }\end{array}$ & $\begin{array}{l}\text { Urban } \\
\text { area (ha) }\end{array}$ & $\begin{array}{l}\text { Density } \\
\text { (people/ha) }\end{array}$ \\
\hline 1986 & 621 & 158.6 & 99.1 & 77999.7 & 79.62 \\
\hline 1991 & 683 & 284.0 & 171.2 & 80589.8 & 84.75 \\
\hline 1996 & 829 & 956.5 & 428.9 & 101780.8 & 81.45 \\
\hline 2001 & 961 & 1657.6 & 635.0 & 116441.6 & 82.53 \\
\hline
\end{tabular}
area was calculated; then the future urban land area was predicted from Eq. (13). The results of the prediction are shown in Table 6 . The prediction based on regression model indicated that urban land would increase significantly in future. The urban land will be 185179.3 ha (Table 6) in 2021, compared to 116441.6 ha (Table 1) in 2001.

Table 5

Non-agriculture population, per capita income of urban population, per capita income of rural population and urban area (100 US $\$=830.6$ RMB) 
Table 6

Prediction of non-agriculture population, per capita income of urban population, per capita income of rural population and urban area (100 US\$ $=830.6$ RMB)

\begin{tabular}{|c|c|c|c|c|c|}
\hline \multirow[t]{2}{*}{ Year } & \multirow{2}{*}{$\begin{array}{l}\text { Non-agriculture } \\
\text { population }(10,000)\end{array}$} & \multirow{2}{*}{$\begin{array}{l}\text { Per capita income of urban } \\
\text { population (US\$ 1) }\end{array}$} & \multirow{2}{*}{$\begin{array}{l}\text { Per capita income of rural } \\
\text { population (US\$ } 1 \text { ) }\end{array}$} & \multicolumn{2}{|l|}{ Urban area (ha) } \\
\hline & & & & Regression prediction & Markov prediction \\
\hline 2006 & 1041 & 2013.5 & 777.0 & 135124.6 & 128483.3 \\
\hline 2011 & 1151 & 2537.0 & 963.1 & 151809.5 & 140203.2 \\
\hline 2016 & 1262 & 3060.5 & 1149.2 & 168494.4 & 151610.2 \\
\hline 2021 & 1372 & 3560.8 & 1335.2 & 185179.3 & 162713.3 \\
\hline
\end{tabular}

\subsection{Markov analysis and change prediction}

To check whether the process of land use change was homogeneous during the full study period, time homogeneous (time stability) was tested by comparing each subperiod transition matrix (Table 2) to the full period transition matrix (Table 2) using the test statistics Eq. (8). The result $\left(K^{(3)}=227,106\right)$ clearly rejected the null hypothesis of time homogeneity $(\alpha=0.05$, d.f. =24). Thus, it is clear that Beijing was undergoing a process of unstable land use from 1986 to 2001.

Time independence (Markov property) during the full study period was tested through two steps. First, Markovity of order 0 was tested using the test statistics Eq. (11). The result $\left(K^{\left(O_{0}\right)}=\right.$ $\left.3.4 \times 10^{8}\right)$ indicated that the null hypothesis of order $0(\alpha=0.05$, d.f. $=25)$ was rejected. Second, order 1 was tested using the test statistics Eq. (12). The result $\left(K^{\left(O_{1}\right)}=55992\right)$ rejected the null hypothesis of order $1(\alpha=0.05$, d.f. $=15)$, indicating that the land use change process under consideration was of a higher order, or dependent of the states at the previous periods, thus the assumption of Eq. (3) was unaccepted. This result indicated that the land use change in Beijing was a time dependent stochastic process.

It is clear that most of the land use change occurred in $1990 \mathrm{~s}$ (Tables 1 and 2). Therefore, it is reasonable to check whether the process of land use change was homogeneous from 1991 to 2001 according to Eq. (8). The full sample period is 1991-2001, and the subperiods are 1991-1996 and 1996-2001. The result $\left(K^{(2)}=31779\right)$ rejected the null hypothesis $(\alpha=0.05$, d.f. $=22)$, which indicated that the process of land use change in the $1990 \mathrm{~s}$ was unstable too.

As a result, the idea that the process of land use change was stationary was rejected through the test. However, the transition probabilities (Table 2) estimated from the full study period with an interval of 5 years might be assumed to be time-stationary Markov transition matrix $P$ and may be used to predict the future land use category distribution to provide answers to 'what if' kinds of questions (Baker, 1989). This prediction was calculated according to Eq. (6), given $P$ was the transition matrix from Table 2, $s(m)$ was land use distribution in area in 2001. The results of this prediction are shown in Table 6.

Both of the two models predicted that if Beijing did not change the current developments in land use, urban land would increase significantly in future. Although the conversion of agricultural land into urban land has been under strict control due to the implementation of the agriculture land protection ordinance since 1994, urban expansion and agriculture land loss in Beijing seemed to be out of the control of the authorities. This unlimited expansion of urban land will aggravate the environmental issues which Beijing has already been confronted.

\section{Discussion}

In China, the land use legislation distinguishes transferable "land use rights" and inalienable "land ownership". According to the land use legislation, there are two types of land ownership, "collective ownership" and "state ownership". Collective ownership land is defined as the land that leased to agricultural people for agricultural production and related actions, and cropland is the collective owned land. State ownership land is defined as urban land and other land that is not leased to agricultural population. The land use legislation permitted the sale of land use rights of state ownership land in the land market, but the sale of land use rights of collective ownership land is not permitted. There are two levels of land markets, the primary market and the secondary land market. Markets for the sale of the rights to the use of state-owned land are known as primary markets, on which land-use right is sold to developers and users by means of public auction, bid or agreement by land administration departments at different levels on behalf of the state. This type of market is totally monopolistic. Markets for the transfer of the right to the use of state-owned land are known as secondary markets, on which developers and administrators carry out development, sales and transfer operations after they have acquired land-use rights according to law. This type of market is totally competitive. There are two steps in cropland becoming land for urban use. First, the local government expropriates collectively owned cropland for public and commercial purposes and compensates peasants whose lands are affected. The compensation standard for this expropriation is based on the annual yield of the land, not the land's market value that is much higher than the value of annual yield. Then the expropriated land becomes state-owned and its land-use rights can be transferred by means of auction, bid or agreement on the first level market. The government and its functional departments constitute a special market entity. On one hand, it is the administrator of the operations in the land market as well as the regulator. On the other hand, it also participates directly in the market activities as a landowner, and can profit from these land trades due to the large value differences between the compensation to the peasants whose land have been expropriated and the market value of the expropriated land. Therefore, the standardization of governmental behaviors is an important prerequisite to the protection of cropland and a healthy land market. 
In the early 1990s, there was an explosive boom of development zones in Chinese cities. From big cities to small towns and from inland areas to coastal harbors, local governments set up numerous economic development zones with many kinds of titles, such as Economic and Technological Development Zone, High Technology Development Zone and Industrial Development Zone. There were 2700 development zones at the end of 1992 compared to only 117 at the end of 1991 in China (Liang and Zhou, 1993). Their sizes varied from a medium-sized city to several parcels of land. Local governments have invested heavily in these zones to provide public services and urban infrastructure such as land grading, electricity, gas, water and roads. Beijing Municipal Government also set up a series of development zones around the city center in the 1990s. Examples are, Zhonguancun and Shangdi High Technology Zone in Haidian, Industrial Development Zone in Shuanyi and Tongzhou, Fengtai High Technology Zone in Fengtai and more than 20 industrial development zones distributed in suburban areas (Beijing Municipal Institute of City Planning and Design Planning Research Department, in litt.). And these booms of development zones made the urban land expand rapidly from big cities to small towns in China in 1990s.

Within the Beijing Municipality area, urban land amounted to $7.1 \%$ of its total area in 2001, and occupied $18.47 \%$ of its plain area, most of which was good quality agricultural land. These figures are much higher than international standards. For example, in New Zealand, urban growth since European settlement represented only $4 \%$ of its highly productive land (Leamy, 1974). In Canada, the same situation was also found in the study by Smit and Cocklin (1981) on the extent of future rural-to-urban land use conversion for each of the 30 Ontario counties for the period 1976-2001. Under the worst scenario, less than $2 \%$ of the prime agricultural land of Ontario would be lost. Edwards (1969) also reached the same conclusion for England and Wales.

Regression results from this study are consistent with hypothesized relationships between urban land area and socioeconomic factors driving the development of urban land. Population and personal income levels of urban area are the primary determinants of urban land increase in Beijing. For urban planning, implications of growth in urban populations and urban land can include increased traffic congestion, conversion of open space, increased commuting times, residential energy consumption (Kahn, 2000), and concerns about changes in quality of life. Changes in quality of life may improve in some cases with increased housing opportunities. Those involved in landscape and urban planning will also recognize that significant expansion of urban land is often an inadvertent byproduct of policies that were designed for other purposes.

Bruijn (1994) indicates that the factors influencing land suitability and hence development probabilities often have a strong 'distance decay function'. Other empirical models include the applications of fractal theory to explain the distributions of various land use types by means of an inverse power function (Batty and Longley, 1994). This study demonstrated the distance decay function in Beijing by using remote sensing data. The parameter values of the function indicated that the influences are in a linear form.
The Markov probabilities estimated from the full study period proved to be useful to analyze and predict the distribution of land use categories, though the land use change process was not stationary according to the tested results. The measurement and prediction of land use change based on regression models and Markov models have important implications for urban planning and management sections of Beijing.

The Markov chain model has shown the capabilities of descriptive power and simple trend projection for land use and land cover change. However, the Markov chain model requires making restrictive assumptions. In the study of land use and landscape literature, these assumptions have been frequently taken for granted (Brown et al., 2000; Lopeza et al., 2001; Hathout, 2002; Luijten, 2003). Based on maximum likelihood estimators for transition probabilities, the present article proposed some statistical tests to check the time stability and time independence of Markov chains of land use change. These tests turned out to be useful tools to test the assumptions. Pearson $\chi^{2}$ goodnessof-fit test is very simple and easy to implement for the analysis of land use change dynamics. There is scope for the statistical judgment of mass information when interpreting the test statistics and when deciding the appropriate steps for further analysis.

The integration of satellite remote sensing, GIS, regression modeling and Markov modeling provides a means to study changes in land uses. Data and computational limits are becoming less significant due to advances in remote sensing for detecting change and in the incorporation of remotely sensed data and auxiliary data into GIS (Baker, 1989). The most compelling research issues may be a lack of understanding of how to incorporate existing knowledge in useful models of land use change.

\section{Acknowledgements}

This study is supported by the National Natural Science Foundation of China (70433001, 40241009). We are grateful for support of Beijing Municipal Institute of City Planning \& Design Planning Research Department.

\section{References}

Alig, R.J., Kline, J.D., Lichtenstein, M., 2004. Urbanization on the US landscape: looking ahead in the 21st century. Landscape Urban. Plann. 69, 219234.

Anderson, J.R., Hardy, E.T., Roach, J.T., Witmer, R.E., 1976. A Land Use And Land Cover Classification system for Use with Remote Sensor Data. U.S. Geol. Survey prof. Paper 964. U.S. Government Printing Office, Washington, DC.

Anderson, T.W., Goodman, L.A., 1957. Statistical inference about Markov chains. Ann. Math. Stat. 28, 89-110.

Baker, W.L., 1989. A review of models of landscape change. Landscape Ecol. 2, 111-133.

Batty, M., Longley, P.A., 1994. Fractal Cities: A Geometry of Form and Function. Academic Press, London.

Beijing Municipal Statistical Bureau, 2002. Beijing's Statistical Yearbook. Chinese Statistical Press, Beijing, China (in Chinese).

Bell, E.J., 1974. Markov analysis of land use change: an application of stochastic processes to remotely sensed data. Socio-Econ. Plan. Sci. 8, 311316.

Bourne, L.S., 1971. Physical adjustment processes and land use succession: a review and central city example. Econ. Geogr. 47, 1-15. 
Brabec, E., Smith, C., 2002. Agricultural land fragmentation: the spatial effects of three land protection strategies in the eastern United States. Landscape Urban. Plann. 58, 255-268.

Brown, D.G., Pijanowski, B.C., Duh, J.D., 2000. Modeling the relationships between land use and land cover on private lands in the Upper Midwest, USA. J. Environ. Manag. 59, 247-263.

Bruijn, C.A., 1994. Spatial factors in urban growth: toward GIS models for cities in development countries. ITC J. 4, 221-231.

Chen, S., Zeng, S., Xie, C., 2000. Remote sensing and GIS for urban growth analysis in China. Photogramm. Eng. Rem. Sens. 66, 593-598.

Drewett, J.R., 1969. A stochastic model of the land conversion process. Reg. Stud. 3, 269-280.

Eastman, J.R., Fulk, M., 1993. Long sequence time series evaluation using standardized principle components. Photogramm. Eng. Rem. Sens. 59, 991-996.

Edwards, A.M., 1969. Land requirement for UK agriculture by the year 2000: a preliminary statement. Town Country Plann. 37, 108-150.

Ehlers, M., Jadkowski, M.A., Howard, R.R., Brostuen, D.E., 1990. Application of SPOT data for regional growth analysis and local planning. Photogramm. Eng. Rem. Sens. 56, 175-180.

Harris, P.M., Ventura, S.J., 1995. The integration of geographic data with remotely sensed imagery to improve classification in an urban area. Photogramm. Eng. Rem. Sens. 61, 993-998.

Hathout, S., 2002. The use of GIS for monitoring and predicting urban growth in East and West St Paul, Winnipeg, Manitoba, Canada. J. Environ. Manag. $66,229-238$.

International Geosphere-Biosphere Program Committee on Global Change, 1988. Toward an Understanding of Global Change. National Academy Press, Washington, DC.

Jahan, S., 1986. The determination of stability and similarity of Markovian land use change processes: a theoretical and empirical analysis. Socio-Econ. Plan. Sci. 20, 243-251.

Jensen, J.R., 1996. Introductory Digital Image Processing: A Remote Sensing Perspective, second ed. Prentice Hall, Upper Saddle River, NJ.

Jensen, J.R., Cowen, D.C., 1999. Remote sensing of urban suburban infrastructure and socio-economic attributes. Photogramm. Eng. Rem. Sens. 65, 611-622.

Kahn, M., 2000. The environmental impact of suburbanization. J. Policy Anal. Manag. 19, 569-586.
Leamy, M.L., 1974. Resources of highly productive land. New Zealand Agric. Sci. 8, 187-191.

Li, X., Yeh, A.G.O., 1998. Principal component analysis of stacked multitemporal images for the monitoring of rapid urban expansion in the Pearl River Delta. Int. J. Remote Sens. 19, 1501-1518.

Liang, Y., Zhou, Y., 1993. Preliminary study on urban development zones. City Plann. Rev. 4, 27-30 (in Chinese).

Lopeza, E., Boccoa, G., Mendozaa, M., Duhaub, E., 2001. Predicting land-cover and land-use change in the urban fringe. A case in Morelia city, Mexico. Landscape Urban. Plann. 55, 271-285.

Luijten, J.C., 2003. A systematic method for generating land use patterns using stochastic rules and basic landscape characteristics: results for a Colombian hillside watershed. Agric. Ecosys. Environ. 95, 427-441.

Mather, A.S., 1999. Land use and cover change. Land Use Policy 16, 143.

Messerli, B., 1997. Geography in a rapidly changing world. IGU Bull. 47, 65-75.

Meyer, W.B., Turner II, B.L., 1991. Changes in Land Use and Land Cover: A Global Perspective. Cambridge University Press, Cambridge.

Muller, R.M., Middleton, J., 1994. A Markov model of land-use change dynamics in the Niagara region, Ontario, Canada. Landscape Ecol. 9, 151157

Robinson, V.B., 1978. Information theory and sequences of land use: an application. Prof. Geogr. 30, 174-179.

Seto, K.C., Kaufmann, R.K., 2003. Modelling the drivers of urban land use change in the Pearl River Delta, China: integrating remote sensing with socioeconomic data. Land. Econ. 79, 106-121.

Smit, B.E., Cocklin, C., 1981. Future urban growth and agricultural land: alternatives for Ontario. Ontario Geogr. 18, 47-55.

State Council, 1994. Ordinance for the Protection of Primary Agricultural Land. State Council, Beijing, China, p. 12 (in Chinese)

The Ministry of Land and Resources P.R.C., 2002. Report of China's land resources 2001. Geology Publication, Beijing (in Chinese).

Turner, M.G., 1990. Landscape changes in nine rural counties in Georgia. Photogramm. Eng. Rem. Sens. 56, 379-386.

United Nations, 2001. World Urbanization Prospects: The 2001 Revision. New York (http://www.un.org/esa/population/pubsarchive/pubsarchive. htm).

Yeh, A.G.O., Li, X., 1999. Economic development and agricultural land loss in the Pearl River Delta. China Habitat. Int. 23, 373-390. 